УДК 346.6

DOI https://doi.org/10.32849/2663-5313/2020.8.11

\author{
Максим Гетманцев, \\ канд. юрид. наук, \\ старший науковий співробітник \\ Науково-дослідного інституту приватного права і підприємниитва \\ імені академіка Ф. Г. Бурчака \\ Начіональної академії правових наук України
}

\title{
НОВЕЛИ ЗАКОНОДАВСТВА УКРАЇНИ ЩОДО ЗАСТОСУВАННЯ РЕЄСТРАТОРІВ РОЗРАХУНКОВИХ ОПЕРАЦІЙ
}

Стаття присвячена питанням якісного оновлення вітчизняного законодавства, внаслідок якого з 1 серпня 2020 року набрали чинності положення про застосування реєстраторів розрахункових операиій у сфері торгівлі, громадського харчування та послуг, дія яких поширюється на усіх суб'єктів господарювання, їх господарські одинииі та представників (уповноважених осіб) суб'єктів господарювання, які здійснюють розрахункові операцї у готівковій та/або безготівковій формі.

Метою статті $\epsilon$ аналіз змісту чинних нормативно-правових актів, що регламентують обов'язковість запровадження реєстраторів розрахункових операчій, та практичних проблем іххреалізації в умовах тотальної інформатизації бізнесу та иифровізації правовідносин.

У сучасному світі глобалізація економіки та інформатизація бізнесу є одними з найбільш потужних трендів у розвитку світового співробітництва різного рівня. Діджиталізація стає важливою детермінантою в активізаиії торговельних операчій, а також відіграє провідну роль в оптимізаиї способів обміну інформачї̈ не лише між контрагентами чи споживачами, але й із фіскальними та іншими контролюючими органами, котрі, своєю чергою, теж все більше видів своєї діяльності переводять у иифровий формат взаємодії. По суті, ступінь інформатизаиї̈ виступає одним з основних показників рівня сочіально-економічного розвитку держави, що об'єктивно неможливо без детальної правової регламентаиії згаданих прочесів.

У иьому контексті законодавча регламентаиія застосування реєстраторів розрахункових операцій потребує негайного вдосконалення та трансформації. Окреслена проблема має комплексний характер: незважаючи на чисельні доповнення відповідного законодавства, прочедура запровадження та використання реєстраторів розрахункових операцій і надалі потребує свого якісного корегування з одночасними змінами профільних нормативно-правових актів. Зокрема, як зазначається в статті, відповідні документи повинні враховувати чимало нюансів (основні поняття $і$ завдання, алгоритм, засоби і механізми їх виконання, перелік органів контролю і порядок їх формування у співпрачі з експертним і науковим середовищем, в тому числі бізнес-середовищем у иій сфері), а зміст, формат і юридичну силу иих документів варто закріпити в законодавстві.

Ключові слова: реєстратори розрахункових операцій, РРО, інформатизація бізнесу, цифровізація, діджиталізація.

Постановка проблеми. Сучасний етап розвитку світової економіки характеризується активізацією процесів діджиталізації у всіх сферах і формах господарсько-економічної діяльності та їх правового забезпечення як невід'ємних складників інформаційного суспільства.

Розрахункові операції, що супроводжують діяльність більшості суб’єктів господарювання, нині заступають у нову віху свого розвитку. Поява найближчим часом нового обов'язкового елемента цієї функціонуючої системи призводить до сутнісного перебалансування ресурсів на ринку товарообігу та послуг. Йдеться про те, що Закон України
«Про внесення змін до Закону України «Про застосування реєстраторів розрахункових операцій у сфері торгівлі, громадського харчування та послуг» та інших законів України щодо детінізації розрахунків у сфері торгівлі та послуг» від 20.09.2019 № 128-IX, який набрав чинності 31 серпня 2020 року, запровадив суттєві зміни до правового забезпечення електронно-касових розрахунків усіх операцій учасників цивільного бізнесу, насамперед це стосується запровадження нових правил використання реєстраторів розрахункових операцій (далі - PРО). Як наголошує О. Вінник, в умовах цифровізації економіки господарські відносини зазнали 
істотних змін, що, зокрема, призвело до появи віртуальних підприємств та віртуальних об'єктів, електронних форм зв'язків, включаючи договори, а також спричинило пов'язані з цим проблеми щодо їх правового режиму, відповідальності тощо [1, с. 60]. Відтепер використання РPO, по суті, є єдиним легітимним механізмом здійснення розрахунків у сфері торгівлі, громадського харчування та послуг.

Зважаючи на наведене, потребує вдосконалення організація готівкового обігу, приведення його у відповідність до потреб ринкової економіки. Не останню роль, за слушним зауваженням В. Стреляного, у цьому відіграє формування досконалої системи поточного фінансового контролю за додержанням порядку проведення готівкових розрахункових операцій, яка забезпечить зменшення неконтрольованого використання готівки суб'єктами підприємницької діяльності, а отже, обмежить роль готівкового обігу як засобу обслуговування руху тіньового капіталу, приховування доходів та ухилення від сплати податків [2, с. 4].

Проблеми цифровізації основних бізнес-процесів загалом та електронних форм проведення базових підприємницьких операцій зокрема постійно перебувають у центрі наукової уваги. Серед тих, хто вибрав предметом своїх аналітичних напрацювань запровадження PРО та особливості їх використання на практиці, з нашого погляду, слід виділити таких правників, як: О. Вінник, C. Івахненков, О. Кравчук, Т. Лук'янова, В. Муравський, А. Павловська, А. Рачинська, В. Стреляний тощо. При цьому, незважаючи на достатню кількість наукових праць, окреслені нами проблемні аспекти запровадження та використання РPO не втрачають своєї актуальності, особливо у світлі законодавчих новел, які набрали чинності з 1 серпня 2020 року. Вкрай важливим у наш час є аналіз та узгодження нормативно-правових приписів, які передбачають різні процедури експлуатації РРО для різних видів надавачів послуг чи відчужувачів товару.

Метою статті $€$ аналіз змісту чинних нормативно-правових актів, що регламентують обов'язковість запровадження PPO, та практичних проблем їх реалізації в умовах тотальної інформатизації бізнесу та цифровізації правовідносин.

Виклад основного матеріалу. Оскільки визначення основних категорій не входить до предмета нашого дослідження, ми оперуватимемо поняттями та їх ознаками, що запропоновані нашими колегами i, на нашу думку, є досить доречними і вичерпними.
Зокрема, Т. В. Лук'янова під обліковим забезпеченням розрахункових операцій пропонує розуміти сукупність інформації стосовно стану розрахунків із дебіторами і кредиторами підприємства, а також способів її обробки та передачі з метою управління фінансовим станом [3, с. 23]. Серед ознак такого облікового контролю В. І. Стреляний виділяє такі: правове регулювання неподатковим законодавством, фактичний характер контрольних заходів, раптовий характер перевірки (без завчасного попередження), крім того, вченим розкрито його самостійний характер у системі фінансового контролю України [2, с. 8-9].

Такі науково-теоретичні підходи базуються на запропонованій ще наприкінці 80-х років минулого століття класифікації, розробленій С. І. Сіняком, який всі без винятку операції за обліковими даними суб’єктів господарювання поділяє на 3 групи. Зокрема, до першої він відносить збір первинних даних, реєстрацію замовлень, розрахунок потреби у матеріалах, ведення інвентаризаційних відомостей, оформлення прийому товарів та їх доставку до покупця, здійснення та оформлення розрахунків з постачальниками та замовниками, виписку з рахунків, розрахунки по заробітній платі та заборгованості перед бюджетом, форматування звітності. До другої групи, на думку автора, слід віднести визначення та встановлення цін, вибір постачальників і замовників, короткострокове прогнозування, поточне управління кадрами. До третьої - довгострокове прогнозування, вибір номенклатури продукції, розроблення фінансово-інвестиційної політики, здійснення кадрової політики. Операції першої групи, на думку автора, можуть бути повністю автоматизовані, другої - підлягають частковій автоматизації з незначною участю управлінського апарату, а операції третьої групи потребують безпосереднього виконання людиною, яка використовує комп'ютер як допоміжний інструмент [4, с. 70].

Водночас такі міркування дозволяють одночасно 3 класифікаційним поділом відкинути і коментарі окремих скептиків, які в оцифровуванні виробничо-звітних процесів вбачають безпосередню загрозу для загального рівня зайнятості населення. Так, на переконання В. Муравського, використання інформаційних технологій у тому числі у системі обліку торговельної діяльності дозволяе значно скоротити кількість обслуговуючого та управлінського персоналу. Відпадає необхідність утримувати в штаті торговельного підприємства касирів, торговельних асистентів, працівників складу та гаражу. Оскільки вся первинна 
інформація збирається повністю автоматизовано, є можливість часткової відмови від складання паперових первинних документів, зокрема: розрахункових документів, документів 3 руху товарів у торговельному закладі, подорожнього листа транспортного засобу тощо [5, с. 76]. Безумовно, доля правди є у цих міркуваннях, проте, як видно з наведеної вище класифікації С. Сіняка, далеко не всі види облікових та інших підзвітних операцій взагалі можливо автоматизувати. Тому очікувати на масштабні хвилі масових звільнень у зв'язку із запровадженням РРО наразі передчасно.

Водночас безпідставним буде і відкидання значної автоматизації багатьох бізнесових процесів, що вже тривалий час активно впроваджується не лише в Україні, але й у цілому світі. При цьому відбувається так би мовити накладення традиційних функцій контрагентів, наприклад продавців і покупців, де класичні обов'язки відчужувача товару може виконувати і потенційний одержувач. Вдалий приклад такого суміщення наводить С. Івахненков, а саме: програмне забезпечення, наприклад, віртуального магазину і з'єднання із системою обліку підприємства таким чином, що бухгалтерські проводки 3 відпуску товару покупцю формуються повністю автоматично. Покупець сам заповнюе на екрані свого комп'ютера бланки замовлень і таким чином, без застосування первинних документів, ініціює проведення фактів реалізації товарів і списання їхньої собівартості. Таким чином, функція 3 реєстрації господарських операцій перекладається на покупця, який взаємодіє з електронним віртуальним магазином і опосередковано із самою системою обліку підприємства-продавця [5, с. 54-56].

Наведене вище дозволяе О. Кравчуку серед недоліків досліджуваного нормативноправового акта називати невиправданим, 3 його точки зору, поширення правил про PРО на ті види розрахункових операцій, які здійснюються у безготівковій формі, оскільки існують бізнеси, котрі не використовують готівку, а здійснюють продаж товарів і послуг через безготівковий розрахунок. Науковець пропонує внести зміни до закону, якими виключити таких підприємців, які безготівково працюють, з числа тих, кому обов'язково мати РPO [6, с. 142-143].

Проте 3 такими зауваженнями неможливо погодитися тому, що абзац перший преамбули Закону України «Про застосування реєстраторів розрахункових операцій у сфері торгівлі, громадського харчування та послуг» чітко визначає, що дія цього нормативно-правового акта поширюється на усіх суб’єктів господарювання, їхні господарські одиниці та представників (уповноважених осіб) суб'єктів господарювання, які здійснюють розрахункові операції у готівковій та/або безготівковій формі. При цьому поза увагою науковців і практиків залишаються випадки, коли всі розрахунки юридичної особи відбуваються так би мовити віддалено (наприклад, якщо всі кошти заходять через розрахунковий рахунок у банку або грошові суми надсилаються через платіжні термінали за умови попередньої ідентифікації контрагента тощо).

У будь-якому разі заслуговує на увагу позиція В. Муравського, який запевняє, що для підприємств, сфера діяльності яких не виходить за межі «торгівля-розрахунокдоставка», можна суттєво скоротити витрати на здійснення як торговельної, так і управлінської діяльності. У майбутньому, із розвитком і масовим впровадженням сучасних інформаційних технологій, можлива повна автоматизація роботи і в інших сферах людської діяльності. Отже, потрібні подальші дослідження щодо застосування таких технологій для потреб облікової практики [5, с. 76].

На практиці реалізація досліджуваних положень потребуватиме доказування не лише самого факту наявності або відсутності РРО у продавця чи надавача послуг, але й багатьох супутніх нюансів, пов'язаних із характеристиками самого РPO та особливостями його використання. Наприклад, в ухвалі про забезпечення доказів у справі № $2 / 331 / 107 / 20$ Жовтневого районного суду м. Запоріжжя від 07 лютого 2020 року окремо наголошено, що до відзиву відповідач у справі не надав жодного доказу, який би підтверджував або спростовував наведені позивачем обставини, у тому числі:

- чи знаходиться у трудових відносинах із відповідачем касир, прізвище якої зазначено на чеку PРО станом на дату продажу товару;

- не надано реєстраційного посвідчення про реєстрацію РРО за офіційною адресою відповідача;

- у яких відносинах перебуває відповідач $з$ особою, прізвище якої разом з іншими зазначено на єдиному чеку РРО, що додавався до претензій та листів тощо.

Як цілком справедливо наголошує О. Кравчук, законодавство щодо застосування PРО у сфері торгівлі, громадського харчування та послуг характеризується наявністю надмірної кількості технічних норм, за порушення яких в окремих випадках передбачено надмірну відповідальність, що в цілому негативно впливає на результати всієї фіскальної політики та розвиток бізнесу [7, с. 143]. 
Також привертає увагу і норма п. 22 Порядку провадження торговельної діяльності та правил торговельного обслуговування на ринку споживачів товарів від 15.06.2006 № 833, згідно з якою суб’єкт господарювання зобов'язаний надати споживачеві разом 3 товаром розрахунковий документ на повну суму проведеної операції, чим підтверджується факт купівлі даного виду товару. Однак, на думку А. А. Рачинської, яку ми поділяємо, досить поширеною є практика продажу товарів з розстроченням платежу або оплатою частинами. Фактично наведена норма забороняє таке розстрочення [8, с. 50].

3 іншого боку, невиправданим було би перекладати провину за численні недопрацьовані моменти лише на законодавця, оскільки практичні складнощі у використанні РPO досить часто зумовлені також i небажанням окремих господарюючих суб'єктів вийти «3 тіні» і намаганням у будьякий спосіб зменшити суми податкових платежів до бюджетів різних рівнів шляхом приховування факту здійснення операцій купівлі-продажу, надання послуг тощо. Як вдало зазначила А. Павловська, приховування обсягу фактично здійснених операцій та отриманих доходів призводить до вилучення коштів з економіки країни. У результаті цього виникає подання недостовірної інформації до органів державної податкової служби України та інших контролюючих органів, а подеколи - перешкоджання споживачам захищати свої права [9, с. 166].

Як бачимо, окреслена проблема має комплексний характер, i, незважаючи на чисельні доповнення відповідного законодавства, процедура запровадження та використання РРО і надалі потребує свого якісного корегування 3 одночасними змінами профільних нормативно-правових актів. Тут доречно взяти до уваги пропозицію Т. І. Швидкої, яка доводить, що відповідні документи повинні враховувати чимало нюансів (основні поняття і завдання, алгоритм, засоби і механізми їх виконання, перелік органів контролю і порядок їх формування у співпраці з експертним і науковим середовищем, в тому числі бізнессередовищем у цій сфері), а зміст, формат і юридичну силу цих документів варто закріпити в законодавстві [10, с. 257].

При цьому головним має бути забезпечення державою не лише адекватності правового регулювання сучасних потреб, наявних та ймовірних загроз цифровізації з притаманною їй віртуалізацією суб'єктів та об'єктів, але й, як наголошує О. Вінник, його (регулювання) прозорості та зрозумілості для пересічних громадян на додаток до подолання цифрової неграмотності та цифрової неспро- можності (брак можливості підтримувати рівень цифрових знань та матеріального забезпечення для їх реалізації у формі наявності відповідних пристроїв, можливості їх обслуговування, оплати послуг Інтернет тощо) [1, с. 60].

\section{Висновки}

Отже, підбиваючи підсумок викладеного вище, варто зауважити, що у сучасному світі глобалізація економіки та інформатизація бізнесу є одними найбільш потужних трендів у розвитку світового співробітництва різного рівня. Діджиталізація стає важливою детермінантою в активізації торговельних операцій, а також відіграє провідну роль в оптимізації способів обміну інформації не лише між контрагентами чи споживачами, але й із фіскальними та іншими контролюючими органами, котрі, своєю чергою, теж все більше видів своєї діяльності переводять у цифровий формат взаємодії. По суті, ступінь інформатизації виступає одним з основних показників рівня соціально-економічного розвитку держави, що об'єктивно неможливо без детальної правової регламентації згаданих процесів. Тому наведені вище недоліки чинного законодавства про РРО мають бути невідкладно усунені.

\section{Список використаних джерел:}

1. Вінник О. Господарські відносини в умовах цифровізації та їх правове регулювання Підприємниитво, господарство $і$ право. 2020. № 5. C. 56-62.

2. Стреляний В. I. Правове регулювання поточного фінансового контролю за додержанням порядку проведення готівкових розрахункових операцій : дис. ... канд. юрид. наук: 12.00.07. Харків, 2010. 203 с.

3. Лук'янова Т. В. Облікове забезпечення розрахункових операцій підприємства: теоретичний аспект. Управління розвитком. 2013 № 23 (163). C. 21-24.

4. Синяк С. И. Безбумажная форма бухгалтерского учета. Москва: Финансы и статистика, $1986.80 \mathrm{c}$.

5. Муравський В. Застосування інформаційних технологій у первинному обліку торговельних, розрахункових і транспортних операцій. Вісник КНТЕУ. Облік та аудит. 2009. № 3. С. 69-76.

6. Івахненков С. В. Інформаційні технології в організації бухгалтерського обліку та аудиту : навчальний посібник. Київ: Знання-Прес, 2003. $349 \mathrm{c}$.

7. Кравчук О. Проблеми фінансово-правового регулювання відносин у сфері застосування реєстраторів розрахункових операцій. Підприємництво, господарство $i$ право. 2017. № 8. C. 139-144. 
8. Рачинська А. А. Окремі питання введення в дію реєстраторів розрахункових операцій для суб'єктів торговельної діяльності. Матеріали науково-практичної конферениї «Наукові тренди постіндустріального суспільства». 2020. Том 2. С. 48-51.

9. Павловська А. С. Типові порушення в обліку касових операцій при застосуванні реє- страторів розрахункових операцій та шляхи їх вирішення. Економічний аналіз, аудит та господарсъкий контроль. 2014. С. 166-167.

10. Швидка T. I. Економічна конкуренція: сучасний стан законодавчого забезпечення та перспективи його модернізації : монографія. Харків : Право, 2020. 376 с.

Maksym Hetmantsev. News of the legislation of Ukraine regarding the application of registrators of settlement operations

The article is devoted to the issues of qualitative updating of domestic legislation, due to which the provisions on the use of registrars of settlement transactions in the field of trade, catering and services came into force on August 1, 2020 which applies to all business entities, their business units and representatives (authorized persons) of business entities that carry out settlement operations in cash and / or non-cash form.

The purpose of the article is to analyze the content of current regulations governing the mandatory introduction of registrars of settlement transactions, and practical problems of their implementation in terms of total informatization of business and digitalization of legal relations.

In today's world, globalization of the economy and informatization of business are among the most powerful trends in the development of global cooperation at various levels. Digitalization is becoming an important determinant in the intensification of trade operations, and also plays a leading role in optimizing the exchange of information not only between counterparties or consumers but also with fiscal and other regulatory authorities, which, in turn, are increasingly digital to digital. interaction format. In fact, the degree of informatization is one of the main indicators of the level of socio-economic development of the state, which is objectively impossible without detailed legal regulation of these processes.

In this context, the legal regulation of the use of registrars of settlement operations need immediate improvement and transformation.

In this context, the legal regulation of the use of registrars of settlement operations needs immediate improvement and transformation. The outlined problem has a complex character and despite numerous additions of the corresponding legislation, the procedure of introduction and use of registrars of settlement operations still needs the qualitative adjustment with simultaneous changes of profile regulations. In particular, as noted in the article, the relevant documents should take into account many nuances (basic concepts and tasks, algorithm, tools and mechanisms for their implementation, the list of control bodies and the order of their formation in cooperation with experts and scientists, including business environment in this area), and the content, format and legal force of these documents should be enshrined in law.

Key words: registrars of settlement operations, RRO, business informatization, digitalization, digitalization. 